НА ДОПОМОГУ ПРАКТИЧНОМУ ЛІКАРЕВІ

Т. М. СОЛОМЕНЧУК, Л. М. КОПЧАК, Г. В. ЧНГРЯН

\title{
АСТЕНІЯ І ЯКІСТЬ ЖИТТЯ ХВОРИХ 3 АРТЕРІАЛЬНОЮ ГІПЕРТЕНЗІЄЮ: ЕФЕКТИВНІСТЬ МЕЛЬДОНІЮ
}

\author{
Львівський національний медичний університет \\ ім. Данила Галицького <profsolomenchuk@ukr.net>
}

\begin{abstract}
Вивчали вплив мельдонію на якість життя та прояви астенії у хворих з артеріальною гіпертензією (АГ). Обстежено 49 пащієнтів, 20 чоловіків (40,8 \%) та 29 жінок (59,2\%). У дослідження не включали хворих із супутніми хворобами, однією з проявів яких є астенія. Методом випадкової вибірки хворих розподілено на дві групи: 25 (I група) отримували лікування АГ згідно з рекомендаціями Свропейського товариства кардіологів (ESC, 2013); 24 (II група) - аналогічне лікування з включенням мельдонію (Тризипін ${ }^{\circledR}$ лонг, ТОВ НВФ “Мікрохім”) у добовій дозі 1000 мг протягом 8 тиж. Пацієнтам проводили стандартне клінічне, лабораторне та інструментальне обстеження з включенням добового моніторування артеріального тиску (ДМАТ). Для оцінки наявності та тяжкості перебігу астенії використовували анкети Multidimensional Fatigue Inventory (MFI-20). Якість життя вивчали за тестом 36-Item Short-Form Health Survey (SF-36). Результати лікування оцінювали як динаміку змін між початком дослідження i через 8 тиж після лікування. При початковому анкетуванні за результатами тесту MFI-20 практично в усіх пацієнтів спостерігали помірні прояви загальної та фізичної астенії. У хворих з АГ та астенією з недостатнім контролем АТ виявлено істотне зниження якості життя, пов'язаної із здоров'ям. Показано, що застосування комбінованої терапії з включенням мельдонію супроводжується достовірним зменшенням проявів астенї та покращанням якості життя на фоні поліпшення контролю за основними показниками ДМАТ.
\end{abstract}

Ключові слова: артеріальна гіпертензія, астенія, якість життя, пов'язана із здоров'ям, MFI-20, SF-36, мельдоній.

Вступ. Метою лікування будь-якого захворювання є відновлення здоров’я пацієнта не лише фізичного, а в широкому його розумінні, важливою складовою якого є якість життя людини - комплексне медичне і соціальне поняття, що визначає фізичне, емоційне та соціальне благополуччя хворого на фоні захворювання і його лікування. У частини пацієнтів захворювання призводить до інвалідності та функціонального дефіциту щодо діяльності індивіда. Багато хронічних захворювань, зокрема артеріальна гіпертензія (АГ), знижують якість життя пацієнта, хоча і не призводять до інвалідності. Відомо, що у разі незадовільного лікування АГ швидко призводить до численних ускладнень, найсерйозніші з яких інфаркт міокарда та головного мозку. Сучасна терапія хворих з АГ спрямована на запобігання цим судинним катастрофам. Водночас психоемоційні проблеми, асоційовані з АГ, часто залишаються поза увагою лікарів, яка спрямована на фізичні аспекти, насамперед зниження артеріального тиску (АТ). При цьому психоемоційні проблеми, серед яких ми виділяємо астенію, у хворих з АГ несприятливо впливають на якість життя більшою мірою, ніж підвищений АТ.

Астенія (fatigue) - хворобливий стан, який проявляється у підвищеній втомлюваності і виснаженні організму, призводить до утруднення фізичної чи психічної діяльності. Принципова відмінність астенічного синдрому від простої втоми полягає в тому, що втома виникає внаслідок виснаження енергетичних запасів, тоді як астенія є наслідком порушення регуляції використання енергетичних ресурсів [1]. Лікарі такий стан діагностують як астенію, однак у пацієнтів середнього 
та похилого віку часто вважають віковими проявами, що не потребують лікування. В основі астенії лежать як психічні (психастенія), так і соматичні причини. Вона є облігатною ознакою таких захворювань, як анемія, гіпотиреоз, злоякісні пухлини, аутоімунні захворювання, ожиріння, бронхіальна астма, СНІД, серцева недостатність, депресія, метаболічні розлади, інфекційні хвороби тощо. Наслідки астенії - ㄲï несприятливий вплив на якість життя, рівень активності, залежність пацієнтів від інших осіб, труднощі у щоденній активності, а для працюючих - погіршення виконання своїх фахових обов'язків. Зазвичай при лікуванні основного захворювання та одужанні пацієнтів прояви астенії зменшуються, хоча при хронічних захворюваннях цього переважно не відбувається.

Астенію, асоційовану з АГ, дослідники відносять до органічного астенічного розладу (шифр за міжнародною класифікацією хвороб 10-го перегляду - F06.6). Клінічними проявами вказаного розладу є надмірна втомлюваність, яка призводить до емоційної лабільності чи неприємних відчуттів, біль, зокрема головний, який є частою скаргою хворих з АГ [6]. Астенія при АГ хронічна, оскільки існує впродовж тривалого часу, перешкоджає життю і діяльності пацієнта і не зникає після відпочинку і сну. Терапевтичні підходи до лікування астенії включають антидепресивні засоби, вегетотропні і метаболічні лікарські засоби (ЛЗ) та психотерапію $[1,5,6]$. Астенію у структурі психічного розладу лікують психостимуляторами і ноотропними Л3 [5]. Терапія соматогенної астенії потребує інших підходів внаслідок необхідності впливу на особливі патогенетичні механізми розвитку.

Анатомічні структури та патогенетичні процеси, що беруть участь у виникненні астенії, нині до кінця не вивчено. На клітинному рівні розвиток астенії асоціюється з порушенням метаболізму енергії у мітохондріях, дисбалансом доставки і переносу енергетичних сполук та розвитком ішемії. Ступінь мітохондріальної дисфункції корелює з тяжкістю астенії [21]. Застосування коректорів метаболічних процесів - L-карнітину, коензиму Q10, піридоксину (віт. $\mathrm{B}_{6}$ ) та ціанокобаламіну (віт. $\mathrm{B}_{12}$ ) - знижує вираженість втоми $[5,16,20,22]$ внаслідок коригуючого впливу на вироблення енергії і поліпшення клітинного метаболізму. Нормалізація функцій мітохондрій, ефективне вироблення енергії поповнюють енергетичний потенціал клітин та приводять до зменшення клінічних проявів астенії.

Одним з широко застосовуваних в Україні метаболічних ЛЗ широкого спектра дії є мельдоній, який гальмує швидкість окислення жирних кислот в мітохондріях, переводячи метаболізм на економніший шлях. Це дозволяє проводити успішну корекцію мельдонієм фізичного стану в осіб із зниженою працездатністю, фізичним напруженням (в тому числі у спортсменів), для оптимізації реабілітації у післяопераційному періоді, при ішемічній хворобі серця, хронічній серцевій недостатності, цереброваскулярній недостатності тощо [2, 8, 9, 14]. Слід зазначити, що дизайн переважної більшості досліджень ефективності мельдонію поряд з вивченням динаміки основних показників серцево-судинної чи мозкової діяльності включав елементи оцінки загального стану пацієнта та якості життя. Зокрема, у подвійному сліпому плацебоконтрольованому дослідженні MILSS [14] виявлено дозозалежний позитивний вплив мельдонію (1000 мг щоденно протягом 12 міс) на толерантність до фізичного навантаження хворих із стабільною стенокардією. В дослідженні INFFANIAM вивчали вплив астенії і функціонального статусу на прогноз хворих на інфаркт міокарда при проведенні черезшкірного коронарного втручання [13]. Інша група дослідників [9] оцінювала вплив мельдонію у складі комплексної терапії на вираженість вторинного соматогенного астенічного синдрому у 180 хворих похилого віку з когнітивними порушеннями на фоні АГ. Призначення мельдонію у різних режимах та дозах показало достовірне зниження кількості хворих з проявами астенічного синдрому при різних захворюваннях. Варто зауважити, що з 1 січня 2016 р. Всесвітнім антидопінговим агентством (WADA) мельдоній віднесено до переліку заборо- 
нених для спортсменів ЛЗ, які стимулюють метаболічні процеси, підвищують фізичну та розумову працездатність, покращують кровопостачання органів i тканин [15].

Імовірний позитивний ефект мельдонію у хворих з АГ може полягати, з одного боку, в індукуванні утворення NO в ендотелії кровоносних судин і зменшенні периферичного опору та покращанні контролю АТ, з іншого, мельдоній нормалізує метаболічні порушення на клітинному рівні, які лежать в основі астенії. Він зменшує гіпоксію тканин та органів-мішеней, покращує їх енергозабезпечення i функціонування, забезпечує корекцію енергообміну в усьому організмі і таким чином зменшує прояви астеніі.

Мета дослідження - вивчення впливу двох режимів лікування (стандартний і $з$ включенням мельдонію) на прояви астенії та якість життя хворих з АГ.

Матеріали і методи. Обстежено 49 хворих з астенією на фоні АГ, 20 (40,8 \%) чоловіків та 29 (59,2 \%) жінок, які зверталися за допомогою в поліклініку сімейної медицини з приводу АГ та скаржились на втому. Пацієнти дали добровільну інформовану згоду на участь у дослідженні. Діагноз АГ встановлювали згідно з Рекомендаціями ЄТГ (2013 ESH/ESC Guidelines for the management of arterial hypertension) [19] та положеннями уніфікованого протоколу [10]. Крім клінічних даних, враховували вік, стать, тривалість захворювання, стадію і ступінь АГ, прийом ЛЗ, фактори ризику серцево-судинних хвороб, супутні хвороби. Додатково в динаміці спостереження проводили контроль за показниками офісного АТ. У майже половини хворих $(n=28 ; 57,14$ \%) здійснювали добовий моніторинг АТ (ДМАТ) за допомогою осцилометричного апарату ВАТ41-1 (Київ, Україна). Аналізували такі показники ДМАТ: середньодобові систолічний АТ, й діастолічний $\mathrm{AT}_{\text {д }}$ і пульсовий $\mathrm{AT}_{\text {п }}$; ступінь нічного зниження АТ за добовим індексом (ДI); варіабельність АТ ( $\mathrm{AT}_{\text {вар }}$ ), індекс часу (IЧ). У дослідження не включали хворих із супутніми психічними розладами та хворобами, облігатною чи факультативною ознакою яких є астенія: депресія, анемія, серцева недостатність, гіпотиреоз, злоякісні пухлини, інфекції, цукровий діабет, неврологічні та аутоімунні захворювання.

Вираженість астенії та якість життя оцінювали шляхом анкетування при першому контакті з пацієнтом і через 8 тиж після лікування. Грунтуючись на результатах досліджень, які визначили астенію як багатовимірне поняття, що враховує фізичне, емоційне та психічне здоров'я, ми використали опитувальник для визначення психометричних властивостей індивіда - Multidimensional Fatigue Invertory (MFI-20) - тест 320 питань, згрупованих у п’ять шкал, призначений для вимірювання п'яти різних аспектів втоми (астенія): загальна астенія (General Fatigue), фізична астенія (Physical Fatigue), знижена активність (Reduced Activity), знижена мотивація (Reduced Motivation) і психічна астенія (Mental Fatigue). Кожна шкала містить чотири питання, що оцінюють за п'ятибальною шкалою $з$ діапазоном значень від 4 до 20, в якій вищі бали вказують на тяжчий ступінь астенії. Сума балів більше 12 за кожною шкалою або загальна сума балів більше 60 свідчить про астенію. Психометричні властивості MFI-20 підтверджено в ряді досліджень [25].

Для оцінки впливу астенії та АГ на якість життя пацієнтів ми використали опитувальник 36-Item Short-Form Health Survey (SF-36) [27], за яким аналізується вісім компонентів якості життя, пов'язаної із здоров'ям: 1) обмеження у фізичній діяльності через проблеми із здоров'ям - Physical functioning (PF); 2) обмеження в соціальній діяльності через фізичні або емоційні проблеми - Social functioning (SF); 3) обмеження у звичайній діяльності через проблеми з фізичним здоров'ям Role-Physical Functioning (RP); 4) фізичний біль - Bodily pain (BP); 5) загальне психічне здоров'я - Mental Health (MH); 6) обмеження у звичайній рольовій діяльності через емоційні проблеми - Role-emotional (RE); 7) життєздатність Vitality (VT) (енергія і втома); 8) сприйняття загального стану здоров’я - General health (GH). Обчислені бали трансформували в шкалу “0-100”, розраховували 
сумарні шкали SF-36 (Mental Component Summary - MCS та Physical Component Summary - PCS). Нижчі бали асоціювалися з гіршою якістю життя, вищі свідчили про задовільну якість життя.

Методом випадкової вибірки хворих розподілено на дві групи. До I групи увійшли 25 хворих з АГ, які отримували лікування згідно з рекомендаціями Європейського товариства кардіологів (ESC, 2013) та Уніфікованого клінічного протоколу медичної допомоги «Артеріальна гіпертензія» [10]; до II групи - 24 хворих, які отримували аналогічне лікування з включенням мельдонію пролонгованої дії (Тризипін ${ }^{\circledR}$ лонг, ТОВ НВФ “Мікрохім”) у добовій дозі 1000 мг протягом 8 тиж. Результати лікування оцінювали як динаміку змін між початком дослідження і через 8 тиж після лікування. Статистичну обробку результатів провели за пакетом програм математичного аналізу Microsoft Excel 2010, дані наведено як $M \pm S D$, достовірність різниці визначали за допомогою $t$-критерію Стьюдента.

Результати та їх обговорення. В основному хворі скаржились на незадовільне самопочуття, загальну слабість, відчуття знесилення, зниження працездатності, втому, головний біль. Середня тривалість скарг становила 2,8 року з коливаннями від 0,5 до 6 років. Серед причин, які передували астенії, пацієнти вказували на стресові ситуації і життєві труднощі. Частина хворих не знаходили зв'язку астенії з певними факторами. Переважна більшість вважали такий стан проявом АГ.

Щодо перебігу АГ як фонового захворювання, то 34,7 \% пацієнтів відмічали часте підвищення АТ, що супроводжувалося суб'єктивним відчуттям запаморочення, шуму у вухах, головним болем, розбитістю тощо. Частина пацієнтів (32,7 \%) не повністю дотримували попередніх призначень лікарів, робили паузи в прийомі антигіпертензивної терапії або приймали ЛЗ лише при значному підвищенні АТ. Критеріям контрольованої АГ відповідали 42,86 \% хворих. Середня тривалість АГ становила 5,84 року з межами від 1,5 до 12,5 року. Ожиріння (індекс маси

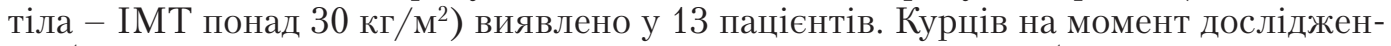
ня було 18. Клінічна характеристика пацієнтів наведена в табл. 1.

Таблиия 1. Клінічна характеристика хворих, які отримували стандартне лікування (I група) та терапію з включенням мельдонію (II група)

\begin{tabular}{lcc}
\hline \multicolumn{1}{c}{ Показник } & I група $(n=25)$ & II група $(n=24)$ \\
\hline \hline Вік, роки & $62,1 \pm 5,5$ & $61,4 \pm 6,9$ \\
Стать, чоловіки/жінки & $9 / 16$ & $11 / 13$ \\
ІМТ, кг/м ${ }^{2}$ & $26,96 \pm 4,71$ & $28,57 \pm 3,97$ \\
Куріння, \% & 32 & 24 \\
Артеріальна гіпертензія, \% & & - \\
І стадія & - & 12,5 \\
II стадія & 8 & 87,5 \\
III стадія & 92 & - \\
І ступінь & - & 75 \\
ІІ ступінь & 68 & 25 \\
ІІІ ступінь & 32 & \\
\hline
\end{tabular}

На початку дослідження практично в усіх пацієнтів обох груп загальна кількість балів за результатами тесту MFI-20 перевищувала 12 як щодо загальної астенії, яка є показником втомлюваності, так і щодо фізичної астенії, що вказує на фізичні відчуття, пов'язані з втомою. Середні значення цих показників становили: загальна астенія - 13,80 $\pm 1,13$ та $14,21 \pm 1,08$, фізична астенія $-14,04 \pm$ 1,08 і 13,67 $\pm 1,03$ (P > 0,05) відповідно для I та II груп (табл. 2).

Водночас, незважаючи на фізичну і загальну втому, у хворих не виявлено зниженої активності як наслідку астенії. Хоча у 16,7 \% хворих показник зниженої активності був вищим за 12 балів, його середні значення в обох групах залишалися нижчими від порогового. Найменш виражені зміни виявили за показниками 
зниженої мотивації та психічної астенії, які у жодного хворого не були вищими за 12 балів (див. табл. 2).

Таблищя 2. Динаміка показників тесту MFI-20 у хворих на фоні стандартного лікування (I група) та з включенням мельдонію (II група) впродовж 8 тиж спостереження ( $M \pm m$ )

\begin{tabular}{l|c|c|c|c|c|c}
\hline \multirow{1}{*}{$\begin{array}{c}\text { Показник } \\
\text { МFI-20 }\end{array}$} & \multicolumn{3}{|c|}{ І група $(n=25)$} & \multicolumn{3}{c}{ II група $(n=24)$} \\
\cline { 2 - 7 } & до лікування & через 8 тиж & $\Delta, \%$ & до лікування & через 8 тиж & $\Delta, \%$ \\
\hline \hline Загальна астенія & $13,80 \pm 1,13$ & $13,64 \pm 1,32$ & $-1,2$ & $14,21 \pm 1,08$ & $11,08 \pm 1,25^{*}$ & -22 \\
Знижена активність & $10,88 \pm 1,14$ & $11,04 \pm 1,08$ & 1,5 & $11,38 \pm 1,25$ & $10,38 \pm 1,03$ & $-8,8$ \\
Знижена мотивація & $8,68 \pm 1,41$ & $8,92 \pm 1,32$ & 2,8 & $8,83 \pm 1,86$ & $8,21 \pm 1,35$ & -7 \\
Фізична астенія & $14,04 \pm 1,08$ & $13,80 \pm 1,20$ & $-1,7$ & $13,67 \pm 1,03$ & $9,96 \pm 1,43^{*}$ & $-27,1$ \\
Психічна астенія & $9,80 \pm 1,06$ & $10,20 \pm 1,33$ & 4,1 & $10,50 \pm 1,76$ & $9,58 \pm 1,22$ & $-8,8$ \\
\hline
\end{tabular}

* $\mathrm{P}<0,05$ при порівнянні показників до та після лікування.

Через 8 тиж після лікування виявлено різницю в динаміці показників MFI-20 у досліджуваних групах. У хворих II групи спостерігали достовірне зниження на 22 \% загальної астенії (від 14,21 $\pm 1,08$ до $11,08 \pm 1,25$; P < 0,05) та на 27 \% фізичної астенії (від 13,67 $\pm 1,03$ до 9,96 $\pm 1,43 ; \mathrm{P}<0,05)$. Незважаючи на досягнення середніх значень $11,08 \pm 1,25$ та 9,96 \pm 1,43 за шкалами загальної та фізичної астенії відповідно, у 3 пацієнтів значення цих показників перевищували порогові 12 балів. Інші показники тесту MFI-20 у II групі мали тенденцію до зниження, однак без досягнення рівня достовірності. У хворих I групи впродовж 8 тиж не відбулося істотного покращання - їхні показники тесту MFI-20 залишилися майже на попередньому рівні, що свідчило про подальше персистування фізичної та загальної астенії.

Таким чином, отримані нами дані показали, що у хворих з АГ є виражені прояви астенії за показниками загальної та фізичної астенії тесту MIF-20. Можливі наслідки астенії полягають в обмеженні активності пацієнтів, які скорочують або уникають фізичного навантаження, щоб обмежити витрату енергії, а застосування мельдонію зменшує прояви фізичної і загальної астенії.

Отримані результати узгоджуються з даними інших досліджень, у яких показано негативний вплив АГ на якість життя, пов'язану із здоров'ям $[17,18,23$, 24, 26]. Однак дослідження впливу астенії на якість життя у хворих з АГ невідомі. Нами вивчено динаміку показників якості життя, пов'язаної із здоров'ям, у хворих з АГ і астенією для кращого розуміння наслідків хвороби та оптимізації лікування (табл. 3 ).

Таблиия 3. Динаміка показників тесту SF-36 у хворих на фоні стандартного лікування (I група) та з включенням мельдонію (II група) впродовж 8 тиж спостереження ( $M \pm m$ )

\begin{tabular}{|c|c|c|c|c|c|c|}
\hline \multirow{2}{*}{$\begin{array}{l}\text { Показник } \\
\text { SF-36 }\end{array}$} & \multicolumn{3}{|c|}{ І група $(n=25)$} & \multicolumn{3}{|c|}{ II група $(n=24)$} \\
\hline & до лікування & через 8 тиж & $\Delta, \%$ & до лікування & через 8 тиж & $\Delta, \%$ \\
\hline $\begin{array}{l}\text { Physical } \\
\text { functioning }\end{array}$ & $58,80 \pm 13,06$ & $57,60 \pm 11,76$ & $-2,04$ & $61,67 \pm 15,86$ & $74,79 \pm 14,61^{*}$ & 21,27 \\
\hline $\begin{array}{l}\text { Role-Physical } \\
\text { Functioning }\end{array}$ & $46,40 \pm 18,30$ & $48,00 \pm 19,90$ & 3,45 & $48,96 \pm 22,22$ & $55,21 \pm 14,40$ & 12,76 \\
\hline Bodily pain & $53,48 \pm 16,89$ & $50,88 \pm 15,75$ & $-4,86$ & $52,75 \pm 17,09$ & $62,79 \pm 16,29^{*}$ & 19,03 \\
\hline General health & $66,56 \pm 14,81$ & $64,96 \pm 15,27$ & $-2,4$ & $58,88 \pm 16,48$ & $69,67 \pm 14,76^{*}$ & 18,32 \\
\hline Vitality & $53,40 \pm 13,83$ & $49,80 \pm 10,91$ & $-6,74$ & $53,95 \pm 14,24$ & $58,54 \pm 12,62$ & 8,51 \\
\hline $\begin{array}{l}\text { Social } \\
\text { functioning }\end{array}$ & $45,50 \pm 15,76$ & $43,50 \pm 11,25$ & $-4,4$ & $46,35 \pm 17,11$ & $54,17 \pm 19,32$ & 16,87 \\
\hline Role-Emotional & $39,96 \pm 18,84$ & $43,29 \pm 18,55$ & 8,3 & $41,63 \pm 19,82$ & $49,95 \pm 21,50^{*}$ & 19,98 \\
\hline Mental health & $53,92 \pm 15,81$ & $55,20 \pm 14,58$ & 2,37 & $55,83 \pm 16,23$ & $60,67 \pm 16,76$ & 8,67 \\
\hline
\end{tabular}

* $\mathrm{P}<0,05$ при порівнянні показників до та після лікування. 
Початкове анкетування показало істотне зниження якості життя, пов’язаної із здоров'ям, хворих з АГ та астенією. Середні значення показників за всіма шкалами знаходились в межах від 39 до 66 \%. Шкали Role-Emotional, Role-Physical Functioning та Social Functioning показали значне зниження якості життя при відносно вищих показниках за шкалами Physical Functioning та General Health. У попередніх дослідженнях [23, 24] було встановлено, що АГ спричинює обмеження як у фізичній, так і у психічній діяльності: у хворих були знижені показники за всіма шкалами SF-36, що узгоджується з даними нашого дослідження. Нами виявлено зниження фізичного та психічного компонентів якості здоров'я, хоча прояви астенії за тестом MFI-20 до більшої міри були пов'язані з фізичною астенією.

Вивчення динаміки змін показників SF-36 після 8 тиж лікування показало різноспрямовані зміни у хворих I групи. Тенденцію до покращання відмічено за шкалами Role-Physical Functioning на 3,45 \%, Role-Emotional - на 8,3 \% та Mental health - на 2,37 \% (всі P > 0,05). Показники решти шкал знизилися на 2,04-6,74 \% вихідного значення, що свідчило про погіршення суб'єктивного сприйняття стану свого здоров'я пацієнтами I групи. Щодо хворих II групи, то повторне визначення якості життя через 8 тиж після лікування свідчило про значне збільшення середніх значень аналізованих показників. Відмічено достовірне підвищення балів за трьома шкалами, які асоціюються з фізичною компонентою якості життя (значення Physical functioning збільшилось на 21,27 \%, Bodily pain - на 19,03 \%, General health - на 18,32 \%), та за однією шкалою, яка характеризує психічну компоненту якості життя (рівень Role-Emotional збільшився на 19,98 \%). Показники решти шкал мали тенденцію до підвищення, однак не досягали достовірного значення при динамічному спостереженні.

Аналізуючи сумарні шкали SF-36 у досліджуваних пацієнтів (табл. 4), ми встановили істотний вплив астенії при АГ на зниження психічної компоненти здоров’я. Водночас включення до лікування мельдонію (Тризипін ${ }^{\circledR}$ ) сприяло покращанню фізичної та психічної компонент здоров'я. На 8-й тиждень терапії у хворих II групи показник MCS збільшився на 5,2 \%, показник PCS - на 10,2 \% $(\mathrm{P}<0,05)$ початкового значення. Показники сумарних шкал у хворих I групи істотно не змінилися впродовж лікування.

Таблиия 4. Динаміка значень показників сумарних шкал SF-36 у хворих на фоні стандартного лікування (I група) та з включенням мельдонію (II група) впродовж 8 тиж спостереження $(M \pm m)$

\begin{tabular}{|c|c|c|c|c|c|c|}
\hline \multirow{2}{*}{ Показник } & \multicolumn{3}{|c|}{ І група $(n=25)$} & \multicolumn{3}{|c|}{ II група $(n=24)$} \\
\hline & до лікування & через 8 тиж & $\Delta, \%$ & до лікування & через 8 тиж & $\Delta, \%$ \\
\hline $\begin{array}{l}\text { Physical } \\
\text { Component } \\
\text { Summary }\end{array}$ & $45,21 \pm 4,7$ & $44,12 \pm 5,08$ & $-2,4$ & $44,68 \pm 6,17$ & $49,22 \pm 4,83^{*}$ & 10,2 \\
\hline $\begin{array}{l}\text { Mental } \\
\text { Component } \\
\text { Summary }\end{array}$ & $37,84 \pm 7,1$ & $38,18 \pm 6,3$ & 0,9 & $38,17 \pm 7,29$ & $40,14 \pm 7,71$ & 5,2 \\
\hline
\end{tabular}

* $\mathrm{P}<0,05$ при порівнянні показників до та після лікування.

На думку М. Theodorou та співавт. [26], АГ слабо пов’язана з фізичною активністю і мобільністю, проте до більшої міри асоційована з тривогою і депресією. Дослідження G.W. Lambert та співавт. також показало зниження якості життя за психічною компонентою SF-36 у хворих з АГ [17]. Виявлено взаємозв'язок між фізичним станом та шкалами психічного здоров'я. В осіб з високим рівнем фізичної компоненти і низькою оцінкою психічного здоров’я відмічено низьку прихильність до лікування [3], що несприятливо впливає на їх прогноз. Разом з тим якість життя хворих з АГ залежить від ступеня контролю за АТ. Тому у хворих 3 
резистентною АГ показники якості життя значно нижчі, ніж у пацієнтів з контрольованою АГ [17].

Ефективність мельдонію зумовлена насамперед його здатністю виявляти цитопротективні ефекти щодо більшості тканин організму людини за рахунок поліпшення (модифікації) енергозабезпечення клітин в умовах ішемії, психічного чи фізичного стресу. Мельдоній блокує фермент $\gamma$-бутиробетаїнгідроксилазу, який регулює синтез карнітину з ендогенного $\gamma$-бутиробетаїну $(\gamma$-ББ). В результаті в мітохонтріях зменшується концентрація недоокислених жирних кислот, посилюється гліколіз та ефективніше використовується кисень, покращуються внутрішньоклітинні енергозатратні процеси. Разом з тим накопичений ендогенний $\gamma$-ББ подібно до ацетилхоліну, діючи на відповідні рецептори в ендотелії, підвищує біосинтез NO та викликає вазодилатацію на рівні мікроциркуляторного русла, що дозволяє додатково збільшити надходження кисню до тканини та ефективно його використовувати [3, 4]. Більш виражена позитивна динаміка підвищення працездатності, зменшення симптомів фізичного і психічного перенапруження у пацієнтів II групи порівняно з I є результатом додаткового «універсального» метаболічного ефекту мельдонію. Згідно з отриманими нами даними, призначення мельдонію дозволяє позитивно впливати на основні компоненти якості життя (Physical functioning, Bodily pain, General health та Role-Emotional) та меншою мірою - на решту шкал.

Для отримання більш повної картини щодо результатів використання двох схем лікування хворих з АГ з ознаками астенії нами проведено аналіз динаміки основних показників ДМАТ, який свідчить про позитивні результати терапії хворих обох груп. Водночас у пацієнтів II групи, які додатково приймали мельдоній, порівняно з хворими I групи спостерігали більш виражену позитивну динаміку основних показників ДМАТ: зниження середньодобового $\mathrm{AT}_{\mathrm{C}}(-19,2$ \% проти $16 \%), \mathrm{AT}_{\text {д }}(-15,6 \%$ проти $-12,2 \%), \mathrm{AT}_{\text {п }}(-25,1 \%$ проти $-21,9 \%)$, показників IЧ $\mathrm{AT}_{\mathrm{C}}(-65,9 \%$ проти $-60,5 \%)$, ІЧ AT $_{\text {п }}$ (-66,8 \% проти $\left.-60,3 \%\right)$, варіабельності AT - вар. AT $_{\text {C }}(-29,5 \%$ проти $-17 \%, \overleftrightarrow{\mathrm{P}}<0,05) ;$ вар. AT $_{\text {д }}(-18,9 \%$ проти $-14,3 \%)$ та збільшення добового індексу - ДІ AT $_{\text {C }}(34,7$ \% проти 22,8 \%, P < 0,05 ), ДI АТ (32,6 \% проти 22,6 \%, P < 0,05) (табл. 5).

Таблиия 5. Динаміка рівнів основних середньодобових показників ДМАТ у хворих обох груп до початку та через 8 тиж після лікування $(M \pm m)$

\begin{tabular}{|c|c|c|c|c|c|c|}
\hline \multirow{2}{*}{ Показник } & \multicolumn{3}{|c|}{ I група $(n=13)$} & \multicolumn{3}{|c|}{ II група $(n=15)$} \\
\hline & до лікування & через 8 тиж & $\Delta, \%$ & до лікування & через 8 тиж & $\Delta, \%$ \\
\hline $\mathrm{AT}_{\mathrm{C}}$, мм рт. ст. & $162,4 \pm 4,2$ & $136,5 \pm 3,6^{*}$ & $-16,0$ & $166,7 \pm 3,5$ & $134,7 \pm 4,5^{*}$ & $-19,2$ \\
\hline $\mathrm{AT}_{\text {д }}$, мм рт. ст. & $99,8 \pm 5,3$ & $87,7 \pm 4,6^{*}$ & $-12,2$ & $102,5 \pm 4,1$ & $86,5 \pm 4,5^{*}$ & $-15,6$ \\
\hline $\mathrm{AT}_{\Pi}$, мм рт. ст. & $62,6 \pm 3,4$ & $48,9 \pm 2,8^{*}$ & $-21,9$ & $64,3 \pm 2,8$ & $48,2 \pm 3,8^{*}$ & $-25,1$ \\
\hline $\mathrm{IU} \mathrm{AT}_{\mathrm{C}}, \%$ & $85,5 \pm 3,2$ & $33,8 \pm 2,7^{*}$ & $-60,5$ & $87,2 \pm 3,5$ & $29,6 \pm 3,9^{*}$ & $-65,9$ \\
\hline IЧ $\mathrm{AT}_{\text {д }}, \%$ & $76,9 \pm 2,6$ & $30,5 \pm 4,2^{*}$ & $-60,3$ & $81,6 \pm 2,6$ & $27,1 \pm 2,8^{*}$ & $-66,8$ \\
\hline $\begin{array}{l}\text { Вар. } \text { AT }_{C} \\
\text { мм рт. ст. }\end{array}$ & $17,1 \pm 1,9$ & $14,2 \pm 2,5^{*}$ & $-17,0$ & $18,3 \pm 1,4$ & $12,9 \pm 1,1^{*}$ & $-29,5^{\#}$ \\
\hline $\begin{array}{l}\text { Вар. } \mathrm{AT}_{\text {Д}} \\
\text { мм рт. ст. }\end{array}$ & $14,7 \pm 1,2$ & $12,6 \pm 1,4$ & $-14,3$ & $15,4 \pm 1,2$ & $12,5 \pm 1,5^{*}$ & $-18,9$ \\
\hline ДІ $\mathrm{AT}_{\mathrm{C}}, \%$ & $7,8 \pm 2,3$ & $10,1 \pm 2,6$ & $+22,8$ & $8,3 \pm 1,8$ & $12,7 \pm 1,7$ & $+34,7^{\#}$ \\
\hline ДІ $\mathrm{AT}_{д}, \%$ & $8,9 \pm 2,5$ & $11,5 \pm 3,0$ & $+22,6$ & $8,7 \pm 1,9$ & $12,9 \pm 2,0$ & $+32,6^{\#}$ \\
\hline
\end{tabular}

" $\mathrm{P}<0,05$ при порівнянні показників до та після лікування.

\# $\mathrm{P}<0,05$ при порівнянні між I і II групами.

Отримані дані узгоджуються з результатами інших дослідників. Зокрема, згідно з результатами рандомізованого дослідження ефективності цитопротекторної терапії хворих на гіпертонічну хворобу II стадії, прийом мельдонію в комплексі з гіпотензивними ЛЗ дозволяє прискорити нормалізацію АТ, покращити його до- 
бовий профіль, зменшити прояви ендотеліальної дисфункції, поліпшити систолодіастолічну функцію лівого шлуночка, сповільнити його ремоделювання, зменшити морфологічні прояви гіпертензивної ангіопатії, знизити інтенсивність вільнорадикальних процесів [7, 11]. Це дозволяє використовувати даний ЛЗ як ефективний компонент вторинної профілактики АГ і пов'язаних з нею ускладнень. Таким чином, мельдоній здатний покращувати стан артеріальних судин за рахунок відновлення функції ендотелію, що, у свою чергу, приводить до кращого контролю за AT. Політропна антигіпоксична і цитопротекторна дія мельдонію [12] може лежати в основі істотного зменшення проявів астенії та відповідно покращання якості життя хворих.

Висновки. У хворих з АГ спостерігаються помірні прояви загальної та фізичної астенії, що в комплексі з недостатнім контролем за АТ істотно знижує якість життя за всіма шкалами тесту SF-36. Призначення хворим з АГ мельдонію (Тризипін ${ }^{\circledR}$ лонг) додатково до базисної антигіпертензивної терапії супроводжується достовірним зменшенням проявів астенії і покращанням якості життя на фоні поліпшення контролю за основними показниками ДМАТ.

$$
\text { Список лі тера тури }
$$

1. Бурчинсъкий С. Г. Ноотропи у фармакотерапії астеноневротичних станів // Медицина світу. - 2004. - Т. XVII, № 6. C. $466-470$.

2. Власова А. В. Лямина Н. П. Качество жизни и факторы его определяющие у больных с хронической сердечной недостаточностью, развившейся после перенесенного инфаркта миокарда // Сердечная недостаточность. - 2002. - № 5. - С. 226-228.

3. Гордеев И. Г,. Лучинкина Е. Е., Хегай С. В. Коррекция дисфункции миокарда у больных стабильной стенокардией, подвергшихся коронарной реваскуляризации, на фоне приёма цитопротектора милдроната / Р Рос. кардиол. журн. - 2009. - Вып. 76, № 2. - С. 54-58.

4. Зупанеи И. А., Шебеко С. К., Отришко И. А. Значение элементов синергической политропности в механизме реализации фармакологического потенциала препарата Капикор // Therapia. - 2015. - Вып. 98, № 5. - C. 48-50.

5. Клименко О. В. Астенія в загальнолікарській практиці // Газета «Здоров’я України». - 2010. - № 18. - С. 21.

6. Куликова Т. Ю. Эффективность и переносимость Фенотропила при терапии астенических расстойств невротического уровня / / Там само. - 2007. - № 8. - С. $23-$ 24.

7. Михин В. П., Хлебодаров Ф. Е. Перспективы применения милдроната у больных с сердечно-сосудистой патологией // Рос. кардиол. журн. - 2010. - № 4. - С. 83-92.

8. Солєйко О. Енергетичний захист міокарда у хворих із хронічною постінфарктною аневризмою лівого шлуночка // Ліки України. - 2004. - № 10. - С. 124-126.
1. Burchins'kij S. G. Nootropi u farmakoterapiï astenonevrotichnih staniv // Medicina svitu. - 2004. - T. XVII, № 6. - C. 466-470.

2. Vlasova A. V.Lyamina N.P. Kachestvo zhizni i faktory ego opredelyayushchie u bol'nyh s hronicheskojserdechnojnedostatochnost'yu, razvivshejsya posle perenesennogo infarkta miokarda // Serdechnaya nedostatochnost'. - 2002. - № 5. - S. 226-228.

3. Gordeev I. G,. Luchinkina E. E., Hegaj S. V. Korrekciya disfunkcii miokarda u bol'nyh stabil'noj stenokardiej, podvergshihsya koronarnoj revaskulyarizacii, na fone priyoma citoprotektora mildronata // Ros. kardiol. zhurn. - 2009. - Vyp. 76, № 2. - S. 54-58.

4. Zupanec I. A., SHebeko S. K., Otrishko I. A. Znachenie elementov sinergicheskoj politropnosti v mekhanizme realizacii farmakologicheskogo potenciala preparata Kapikor // Therapia. - 2015. - Vyp. 98, № 5. - S. 4850.

5. Klimenko O. V. Asteniya v zagal'nolikars'kij praktici // Gazeta «Zdorov'ya Ukraïni». 2010. - № 18. - C. 21.

6. Kulikova T. Yu. EHffektivnost' i perenosimost' Fenotropila pri terapii astenicheskih rasstojstv nevroticheskogo urovnya // Tam samo. - 2007. - № 8. - C. 23-24.

7. Mihin V. P., Hlebodarov F. E. Perspektivy primeneniya mildronata u bol'nyh s serdechnososudistoj patologiej // Ros. kardiol. zhurn. - 2010. - № 4. - S. 83-92.

8. Solejko O. Energetichnij zahist miokarda u hvorih iz hronichnoyu postinfarktnoyu anevrizmoyu livogo shlunochka // Liki Ukraïni. - 2004. - № 10. - S. 124-126. 
9. Стаценко М. Е., Недогода С. В., Туркина C. В. и др. Астенические расстройства у пациентов пожилого возраста с артериальной гипертензией: возможности коррекции астении мельдонием // Рац. фармакотерапия в кардиологии. 2013. - Вып. 9, № 1. - С. 25-30.

10. Уніфікований клінічний протокол первинної, екстреної та вторинної (спеціалізованої) медичної допомоги «Артеріальна гіпертензія» / Наказ МОЗ України № 384 від 24.05.2012 р. «Про затвердження та впровадження медикотехнологічних документів зі стандартизації медичної допомоги при артеріальній гіпертензії» // http://moz.gov.ua/ ua/portal/dn_20120524_384.html.

11. Хлебодаров $\bar{\Phi}$. Е., Михин В. П. Роль цитопротекторов в лечении больных артериальной гипертонией на фоне терапии эналаприлом // Рос. кардиол. журн. 2009. - № 5. - C. 46-50.

12. Чекман И. С., Горчакова Н. А., Франиузова С. Б. и др. Метаболитные и метаболитотропные препараты в системе кардиои органопротекции. - К., 2009. - 155 с.
9. Stacenko M. E., Nedogoda S. V., Turkina S. V. i dr. Astenicheskie rasstrojstva u pacientov pozhilogo vozrasta s arterial'noj gipertenziej: vozmozhnosti korrekcii astenii mel'doniem // Rac. farmakoterapiya v kardiologii. 2013. - Vyp. 9, № 1. - S. 25-30.

10. Unifikovanij klinichnij protokol pervinnoï, ekstrenoï ta vtorinnoï (specializovanoï) medichnoï dopomogi «Arterial'na gipertenziya» / Nakaz MOZ Ukrayni № 384 vid 24.05.2012 r. «Pro zatverdzhennya ta vprovadzhennya mediko-tekhnologichnih dokumentiv zi standartizaciï medichnoï dopomogi pri arterial'nij gipertenziï»// http://moz.gov.ua/ua/portal/ dn 20120524 384.html.

11. Hlebodarov F. E., Mihin V.P. Rol' citoprotektorov v lechenii bol'nyh arterial'noj gipertoniej na fone terapii ehnalaprilom // Ros. kardiol. zhurn. - 2009. - № 5. - S. 46-50.

12. Chekman I. S., Gorchakova N. A., Francuzova $S$. B. i dr. Metabolitnye i metabolitotropnye preparaty v sisteme kardio- i organoprotekcii. - K., 2009. - $155 \mathrm{~s}$.

13. Ariza-Solé A., Formiga F., Vidán M.T. et al. Impact of frailty and functional status on outcomes in elderly patients with $S T$-segment elevation myocardial infarction undergoing primary angioplasty: rationale and design of the IFFANIAM Study / / Clin. Cardiology. - 2013. - Vol. 36, N 10. - P. 565-569.

14. Dzerve V. MILSS I Study Group. A dose-dependent improvement in exercise tolerance in patients with stable angina treated with mildronate: a clinical trial "MILSS I" // Medicina (Kaunas). - 2011. - Vol. 47, N 10. - P. 544-551.

15. http://list.wada-ama.org/list/s4-hormone-and-metabolic-modulators/

16. Konerman M., Weeks K. R., Shands J. R. Short Form (SF-36) Health Survey measures are associated with decreased adherence among urban african americans with severe, poorly controlled hypertension // J. Clin. Hypertens. - 2011. - Vol. 13. - P. 385-390.

17. Lambert G. W., Hering D., Esler M. D. et al. Health-related quality of life after renal denervation in patients with treatment-resistant hypertension // Hypertension. - 2012. - Vol. 60. P. $1479-1484$.

18. Liang X.-Y., Nie S.-F., Qu K.-Y. et al. Evaluation of health-related quality of life among hypertensive patients in a rural area, PR China // J. of Human Hypertension. - 2006. Vol. 20. - P. 227-229.

19. Mancia G., Fagard R., Narkiewicz K. et al. 2013 ESH/ESC Guidelines for the management of arterial hypertension: the Task Force for the management of arterial hypertension of the European Society of Hypertension (ESH) and of the European Society of Cardiology (ESC) // J. Hypertens. - 2013. - Vol. 31, N 7. - P. 1281-1357.

20. Mizuno K., Tanaka M., Nozaki S. et al. Antifatigue effects of coenzyme Q10 during physical fatigue // Nutrition. - 2008. - Vol. 24, N 4. - P. 293-299.

21. Myhill S., Booth N. E., Mac Laren-HowardJ. et. al. Chronic fatigue syndrome and mitochondrial dysfunction // International Journal of Clinical and Experimental Medicine. - 2009. - Vol. 2, N 1). - P. 1-16.

22. Plioplys A. V., Plioplys S. Amantadine and L-carnitine treatment of chronic fatigue syndrome // Neuropsychobiology. - 1997. - Vol. 35, N 1. - P. 16-23.

23. Poljičanin T., Ajduković D., Šekerija M. et al. Diabetes mellitus and hypertension have comparable adverse effects on health-related quality of life. // BMC Public Health. - 2010. - Vol. 10, N 1. P. 12. Published online 2010 January 13. doi: 10.1186/1471-2458-10-12.

24. Shanableh S., Abdulkarem A., Shamssain M. et al. Quality of life of hypertensive patients on different types of antihypertensive medications // IOSR Journal of Pharmacy. - 2014. - Vol. 4 (Issue 5). - P. 23-28. 
25. Smets E. M., Garssen B., Bonke B. et al. The Multidimensional Fatigue Inventory (MFI): psychometric qualities of an instrument to assess fatigue // J. Psychosom. Res. - 1995. - Vo 1. 39. P. 315-325.

26. Theodorou M., Kaitelidou D., Galanis P. et al. Quality of life measurement in patients with hypertension in Cyprus // Hellenic J. Cardiol. - 2011. - Vol. 52, N 5. - P. 407-415.

27. Ware J. E., Sherbourne C. D. The MOS 36-item short-form health survey (SF-36): conceptual framework and item selection // Med. Care. - 1992. - Vo 1. 30. - P. 473-483.

\title{
АСТЕНИЯ И КАЧЕСТВО ЖИЗНИ БОЛЬНЫХ С АРТЕРИАЛЬНОЙ ГИПЕРТЕНЗИЕЙ: ЭФФЕКТИВНОСТЬ МЕЛЬДОНИЯ
}

\section{Т. М. Соломенчук, Л. М. Копчак, Г. В. Чнгрян (Львов)}

Изучали влияние мельдония на качество жизни и проявления астении у больных с артериальной гипертензией (АГ). Обследовано 49 пациентов, 20 (40,8 \%) мужчин и 29 (59,2 \%) женщин. В исследование не включали больных с сопутствующими болезнями, одним из проявлений которых является астения. Методом случайной выборки больных разделили на две группы: 25 больных (I группа) получали лечение АГ согласно рекомендациям Европейского общества кардиологов (ESC, 2013). 24 больных (II группа) - аналогичное лечение с включением мельдония (Тризипин ${ }^{\circledR}$ лонг, ООО НПФ «Микрохим») в суточной дозе 1000 мг в течение 8 нед. Пациентам проводили общепринятое клиническое, лабораторное и инструментальное обследование, включая суточное мониторирование артериального давления - АД (СМАД). Наличие и выраженность астении оценивали с помощью анкеты Multidimensional Fatigue Invertory (MFI-20). Качество жизни изучали с помощью теста 36-Item Short-Form Health Survey (SF-36). Результаты лечения оценивали как динамику изменений исследуемых показателей в начале исследования и через 8 нед после лечения. При начальном анкетировании по результатам теста MFI-20 практически у всех пациентов наблюдали умеренные проявления общей и физической астении. У больных с АГ с астенией и с недостаточным контролем за АД выявлено существенное снижение качества жизни, связанной со здоровьем. Показано, что применение комбинированной антигипертензивной терапии с включением мельдония сопровождается достоверным уменьшением проявлений астении и улучшением качества жизни на фоне улучшения контроля за основными показателями СМАД.

Ключевые слова: артериальная гипертензия, астения, качество жизни, MFI-20, SF-36, мельдоний.

\section{FATIGUE AND QUALITY OF LIFE IN PATIENTS WITH ARTERIAL HYPERTENTION: EFFECTIVENESS OF MELDONIUM}

\author{
T. M. Solomenchuk, L. M. Kopchak, G. V. Tshngryan (Lviv, Ukraine) \\ Lviv National Medical University named after Danylo Galytsky
}

The aim of the study was to investigate the influence of meldonium (Trizipine ${ }^{\circledR}$ Long) on the health-related quality of life (HRQL) and fatigue in patients with arterial hypertension (AH). A total of 49 hypertensive outpatients with fatigue, 20 male (40.8\%) and 29 female $(59.2 \%)$ were examined. The study did not involve patients with concomitant diseases, symptom of which is fatigue. Participants were divided into 2 groups. Twenty-five patients (group 1) received antihypertensive treatment according to the guidelines of the European Society of Cardiology (ESC, 2013). Twentyfour patients (group 2) received antihypertensive treatment with the addition of $1000 \mathrm{mg}$ of meldonium once a day for 8 weeks. The examination included routine clinical, laboratory, and instrumental investigations, including ambulatory blood pressure monitoring (ABPM). The Multidimensional Fatigue Inventory (MFI-20) questionnaire was used to assess the presence and severity of fatigue. The HRQL was assessed by 36-Item Short-Form Health Survey test (SF-36.) The results were evaluated at first appointment and after 8 weeks of treatment. Almost all the patients suffered from moderate fatigue in two subscales: General Fatigue and Physical Fatigue, according to MFI-20 test. In hypertensive patients suffering from fatigue, with poor blood pressure control, we found a significant decrease of HROL. It has been shown that the use of antihypertensive therapy with the addition of meldonium results in significant reduction in fatigue and improving of HRQL as well as improving of the ABPM main data.

Key words: arterial hypertension, fatigue, quality of life, MFI-20, SF-36, meldonium. 